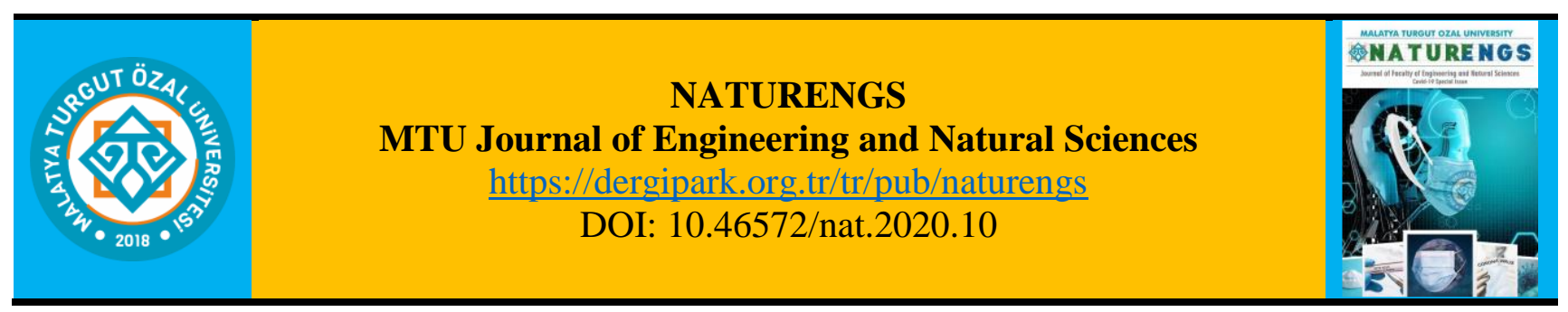

\title{
A Research on Academician Opinions on Distance Education in the COVID-19 Process
}

\author{
Mustafa AKSOĞAN ${ }^{1 *}$, Meral ÇALIŞ DUMAN ${ }^{2}$ \\ 1Computer Programming, Akcadag Vocational School, Malatya Turgut Ozal University, Malatya, Turkey. \\ 2Business Management, Akcadag Vocational School, Malatya Turgut Ozal University, Malatya, Turkey.
}

(Received: 24.10.2020; Accepted: 05.11.2020)

\begin{abstract}
With the Covid-19 pandemic process, educational activities all over the world faced a great challenge. This epidemic, which has a very high risk of transmission, prevented students from taking lessons in the classroom, created social distances and made distance education compulsory. While distance education offers a solution to prevent interruption of educational activities during the pandemic process, on the other hand, it requires teachers and students to adapt to new learning roles through information technologies in order to be successful. However, the adequacy or success of the distance education process is also discussed. The views of the educator (academician) using distance education on this subject are very important. This research is important in terms of reflecting the views of academics. Within the scope of the research, the views of academicians at a state university in the Eastern Anatolia Region on distance education were examined. An online questionnaire was sent to all academicians at this university and evaluations were made over 93 academics who returned to the questionnaires. The data were analyzed with the SPSS 25 package program. As a result of the data obtained, it was seen that the academicians had both positive and negative opinions about distance education. In particular, female academics' opinions on distance education are more positive. However, factors such as age, experience, and title did not affect views on distance education. Again, most of the academicians do not find distance education alone sufficient but think that it will be much more effective when reinforced with formal education.
\end{abstract}

Keywords: Covid-19, Pandemic, Online Learning, Distance Education, Educational Opinions.

\section{INTRODUCTION}

In December 2019, an unknown pneumonia case was recorded for the first time in Wuhan, China. Later, the disease-causing virus was named the SARS-CoV-2 (COVID-19), and this virus which led to a large epidemic worldwide. This epidemic was announced by the World Health Organization as a global pandemic on March 11, 2020 [1, 2]. Although life has come to a standstill in many parts of the world during the pandemic, there have been rapid developments in the use of different methods and practices to adapt to this process [3]. These developments have been seen in many areas from health to transportation, culture to tourism, economy to finance. One of the areas where rapid developments are education [4].

The first precaution taken all over the world regarding education was the close of schools. However, as the process took longer, it was understood that this solution was not sufficient, and distance education studies have been started [3]. Working online has become much easier by developing new platforms for distance education, especially in line with educational 
technologies. For example, virtual classrooms such as Google Meet, Zoom, Moodle, Google Classroom, Microsoft teams, Canvas have started to be used widely [1-5].

Distance education is an innovative education system that is independent of time and place, takes place entirely in virtual environments where learners with teachers do not have to come together [6]. Distance education can also be defined as a system that brings an important solution to inequality of opportunity in education, meets the educational needs of students, is based on the use of educational technologies and more self-learning [7]. Distance education is an important part of the education process and its positive results can be listed as follows [8]:

- Convenience: 24/7 access from any online computer.

- Enhanced learning: emphasizes writing skills, technology skills, life skills such as time management, independence and self-discipline.

- Balancing the playing field: students can spend more time thinking and delving before communicating; shy students tend to do well online.

- Interaction: increased student-teacher and student-student interaction and discussion.

- Innovative teaching: student-centered approaches; the increasing variety and creativity of learning activities; experience of different learning styles.

- Improved management: time to review student work more comprehensively; the ability to document and record online interactions.

- Austerity: reaching more students; increased student satisfaction, less repetition.

- Maximum use of physical resources: reducing the demand for limited campus infrastructure.

- Social assistance: Increasing the educational options of students and easy access to new students.

In some studies on student's satisfaction with distance education, it has been stated that there is an important link between students' easy access to distance education and their level of use. The ability of students to attend classes comfortably from wherever they want has a significant effect on their satisfaction [2].

Distance education will inevitably become a part of education in the future. The pandemic has accelerated this process and demonstrated some benefits with sample applications. For example, with distance education, students and residents in medical education have been allowed to quickly learn the basics of health care. In addition, medical students were able to learn from experts on topics of interest by attending free of charge online conferences and webinars of many medical associations [9]. In some studies in the field of medical education in India, it has been observed that the educators stated that distance education helps to maintain the continuity of educational programs and serves the purpose of completing the current academic year. Accordingly, distance education not only benefited students but also created a continuous education momentum in the country [10].

In addition, in order to be successful in distance education, it is also important to know the duties, abilities and readiness of the learner, teacher and technical team who have taken on different roles in the system. Providing technical infrastructure, establishing virtual classrooms, creating course materials by educators and system domination are among the factors that affect the success of the process [7]. Otherwise, the distance education system will present some disadvantages. For example [1]; 
- Inequality of opportunity in education due to insufficient technical tools and infrastructure (computer, tablet, phone tools, internet infrastructure)

- Not being able to provide a home working environment while taking online lessons

- Worse / lower academic achievement

- Not yet adapting to online learning, not knowing the system

- More absenteeism compared to formal education, desire not to attend classes

- The notion that taking online lessons is unsafe, etc.

In addition to these disadvantages, worry, concern and anxiety disorders that occur in family members during the pandemic process have also been a problem in distance education. It has been stated that parental anxiety and stress are positively associated with child anxiety [4]. For this reason, educators should pay attention to understanding the psychology of students who receive distance education in the home environment, empathy and equal opportunity. To face all the challenges, distance educators must be careful, flexible, willing to face changes and use smart technologies and do not panic [5]. In particular, educators should train themselves in the acquisition of digital skills, technology literacy and cybersecurity [11].

\section{Purpose of the Research}

Users' opinions, satisfaction and perceptions about distance education differ. Due to the differences and widespread use of distance education, there is a significant increase in the number of studies on distance education. However, most of the studies are aimed at determining students' opinions and attitudes towards distance education. Whereas, the number of studies on the opinions of educators and experts on the subject is limited. Therefore, in this study, the opinions of educators and experts on distance education, which has become a part of education in the Covid-19 process, were examined. For this reason, the research has been discussed within the framework of the following sub-problems:

1- What are the general views of the participants on distance education?

2- Is there a significant difference by gender in the general views of the participants on distance education?

3- Is there a significant difference by participant's age in the general views of the participants on distance education?

4- Is there a significant difference by participant's titles in the general views of the participants on distance education?

5- Is there a significant difference by participant's experience in the general views of the participants on distance education?

6- Is there a significant difference in the general views of the participants regarding distance education according to their status of thinking that distance education is an effective model?

\section{MATERIAL AND METHODS}

The general screening model was used in the study. The general screening model involves studies on the entire universe or a sample to be taken from it in order to make a general judgment about the universe in a universe consisting of many elements [12]. 


\subsection{Participant Group}

The research's participant group is composed of academicians working in a university in Turkey. Non-random - voluntary sampling method was used for sample selection. This sampling is a voluntary method in which the person or individuals voluntarily participate in the research [13]. The online questionnaire link has been delivered to all academics. The sample group of the research consists of 93 academics who fill the questionnaire completely. The data regarding the demographic characteristics of the participants are shown in Table 1.

Table 1. Data on the demographic characteristics of the participants

\begin{tabular}{|c|c|c|c|c|c|}
\hline GENDER & $f$ & $\%$ & EXPERIENCE & $f$ & $\%$ \\
\hline Female & 42 & 45.2 & $0-3$ years & 26 & 28.0 \\
\hline Male & 51 & 54.8 & 4-7 years & 9 & 9.7 \\
\hline AGE & $f$ & $\%$ & $8-11$ years & 29 & 31.2 \\
\hline $23-33$ & 28 & 30.1 & 12- 15 years & 11 & 11.8 \\
\hline $34-44$ & 38 & 40.9 & 16 years and over & 18 & 19.4 \\
\hline 45 and over & 27 & 29.0 & \multirow{2}{*}{$\begin{array}{l}\text { Have you received orientation training on } \\
\text { distance education? }\end{array}$} & \multirow{2}{*}{$f$} & \multirow{2}{*}{$\%$} \\
\hline TITLE & $f$ & $\%$ & & & \\
\hline Lecturer & 30 & 32.3 & Yes & 15 & 16.1 \\
\hline Lecturer Dr. & 11 & 11.8 & No & 78 & 83.9 \\
\hline Assistant Prof. & 26 & 28.0 & \multirow{2}{*}{$\begin{array}{l}\text { Do you think distance education is an effective } \\
\text { education model? }\end{array}$} & \multirow{2}{*}{$f$} & \multirow{2}{*}{$\%$} \\
\hline Associate Prof. & 16 & 17.2 & & & \\
\hline Professor & 10 & 10.8 & Yes & 40 & 43.0 \\
\hline TOTAL & 93 & 100 & No & 53 & 57.0 \\
\hline
\end{tabular}

As seen in Table 1, the academians who participated in the survey consisted of 42 female and 51 male. Again, 28 of the participants are between the ages of 23-33, 38 are between the ages of 34-44 and 27 are the ages 45 and over. Looking at the titles of the participants, there are 30 Lecturer, 11 Lecturer Dr., 26 Assistant Prof., 16 Associate Prof. and 10 Professors. In addition, it is seen that most of the participants $(72 \%)$ have more than 4 years of job experience. On the other hand, the rate of participants who did not receive orientation training related to education is $83.9 \%$, while the rate of participants who argue that distance education is an effective education model is $43 \%$.

\subsection{Data Collection Method}

In our study, a questionnaire prepared by the researchers was used to determine the views of academics about distance education. During the questionnaire development process, firstly, a literature review was conducted in which student views on distance education were investigated. Later, the items in the questionnaires developed on the subject were reformatted in line with our research questions and an item pool was created. The data obtained were analyzed by the researchers, and 24 attitude statements that were thought to be related to academians' views on distance education were determined. The draft form of the questionnaire consisting of 24 items was submitted for expert opinion to determine the content validity, and some statements were corrected by the recommendations of the experts. In addition, 6 items that were not suitable for the study or were difficult to understand were removed from the scale in line with expert opinions.

It was not possible to reach academicians face to face due to the restrictions imposed during the pandemic process in our country. That's why the questionnaire has been published online. The survey consists of two parts. The first part of the survey included demographic information. In 
the second part of the questionnaire, there are 18 statements to get academians views on distance education. The academians were asked to mark to what extent agree (1- minimum agree or disagree, 5- maximum agree) to these statements. Reliability analysis of the questionnaire used in the study was made and the Cronbach's alpha value was found to be 0.78 . Cronbach's Alpha value must be greater than 0.7 for a reliable survey. The value of 0.78 indicates that the survey questions are reliable.

\subsection{Data Analysis}

The data obtained are analyzed with SPSS 25 package program. First of all, it was analyzed whether the data showed normal distribution or not. If the sample size is larger than 35 , the Kolmogorov-Smirnov test can be applied [14], and if it is small, the Shapiro-Wilk test can be applied [15]. The Kolmogorov-Smirnov test was applied and the results are shown in Table 2.

Table 2. Test of Normality (Kolmogorov-Smirnov)

\begin{tabular}{|c|c|c|}
\hline Statistic & df & p \\
\hline 0.076 & 93 & 0.200 \\
\hline
\end{tabular}

The fact that the calculated p-value as a result of the test is higher than $\alpha=0.05$ indicates that the data has a normal distribution. Accordingly, it can be assumed that the data are distributed normally. For this reason, independent samples t-test and ANOVA tests, which are among the parametric tests, were used in the analysis of the data.

\section{RESULTS AND DISCUSSION}

In this section, the answers given by academians about distance education and the results of the analysis will be given.

Table 3. Frequency and Percentage Distribution of Academicians' Answers Regarding Distance Education During the Pandemic Process

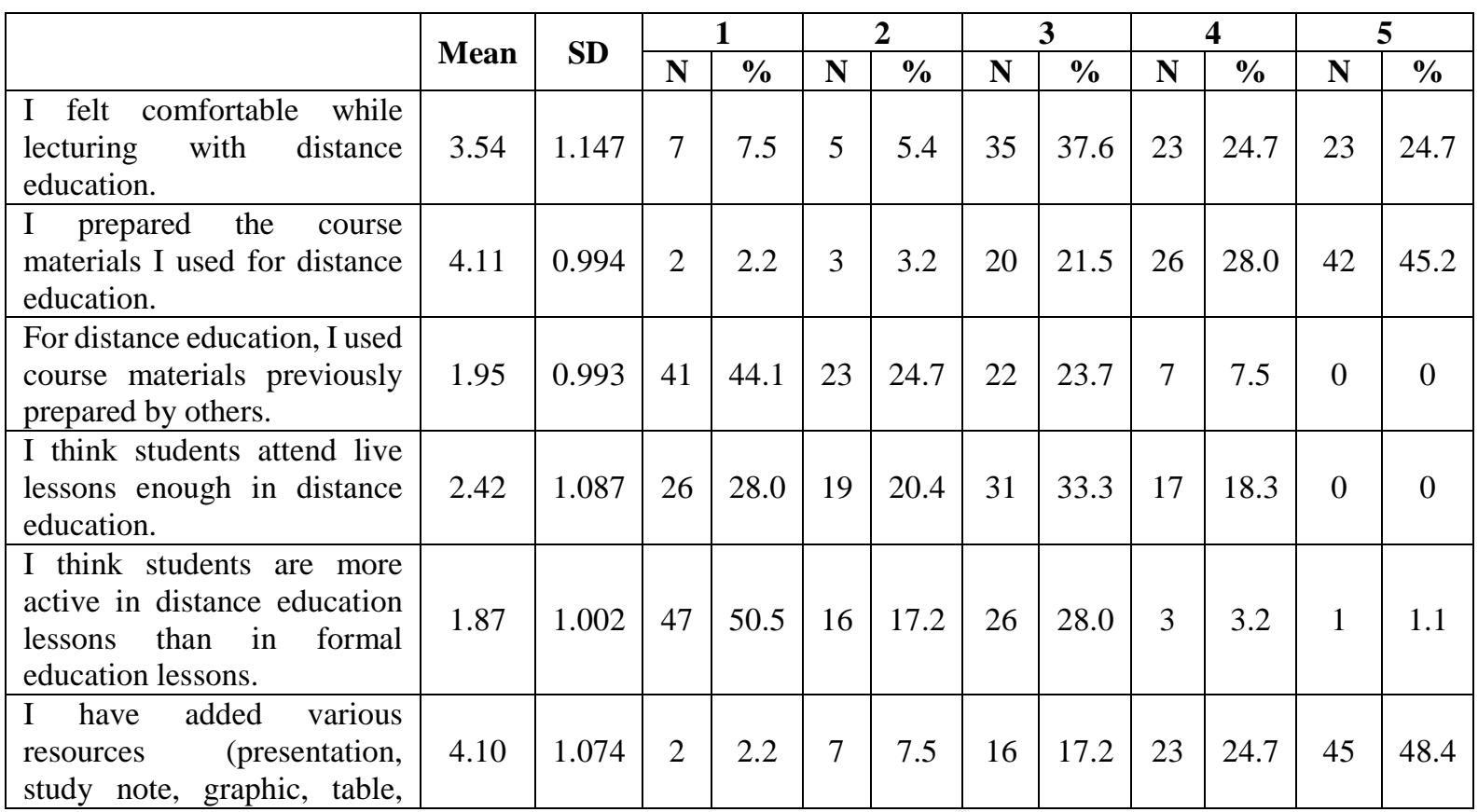




\begin{tabular}{|c|c|c|c|c|c|c|c|c|c|c|c|c|}
\hline $\begin{array}{l}\text { etc.) to the system so that } \\
\text { students can benefit from } \\
\text { distance education lessons. }\end{array}$ & & & & & & & & & & & & \\
\hline $\begin{array}{l}\text { Distance education is at least } \\
\text { as effective as formal } \\
\text { education. }\end{array}$ & 2.39 & 1.189 & 32 & 34.4 & 12 & 12.9 & 33 & 35.5 & 13 & 14.0 & 3 & 3.2 \\
\hline $\begin{array}{l}\text { Distance education alone is } \\
\text { not enough for effective } \\
\text { learning. }\end{array}$ & 3.83 & 1.396 & 13 & 14.0 & 2 & 2.2 & 15 & 16.1 & 21 & 22.6 & 42 & 45.2 \\
\hline $\begin{array}{l}\text { I can use distance education } \\
\text { to support formal education } \\
\text { in the upcoming period. }\end{array}$ & 2.77 & 1.278 & 21 & 22.6 & 18 & 19.4 & 22 & 23.7 & 25 & 26.9 & 7 & 7.5 \\
\hline I think online exams are safe. & 2.52 & 1.129 & 20 & 21.5 & 27 & 29.0 & 29 & 31.2 & 12 & 12.9 & 5 & 5.4 \\
\hline $\begin{array}{l}\text { I don't think that the } \\
\text { activities (homework, } \\
\text { projects, etc.) given to } \\
\text { students in online } \\
\text { environments are safe. }\end{array}$ & 2.73 & 1.303 & 22 & 23.7 & 18 & 19.4 & 26 & 28.0 & 17 & 18.3 & 10 & 10.8 \\
\hline $\begin{array}{l}\text { I don't think that practice- } \\
\text { based courses can be taught } \\
\text { effectively with distance } \\
\text { education. }\end{array}$ & 4.01 & 1.379 & 10 & 10.8 & 4 & 4.3 & 15 & 16.1 & 10 & 10.8 & 54 & 58.1 \\
\hline $\begin{array}{l}\text { I don't think that students pay } \\
\text { enough attention to distance } \\
\text { education lessons. }\end{array}$ & 3.49 & 1.203 & 6 & 6.5 & 12 & 12.9 & 30 & 32.3 & 20 & 21.5 & 25 & 26.9 \\
\hline $\begin{array}{l}\text { I think that I am not as useful } \\
\text { as formal education when } \\
\text { teaching students with } \\
\text { distance education. }\end{array}$ & 3.39 & 1.286 & 9 & 9.7 & 14 & 15.1 & 26 & 28.0 & 20 & 21.5 & 24 & 25.8 \\
\hline $\begin{array}{l}\text { Since recording live lectures } \\
\text { allows students who cannot } \\
\text { attend the lecture to follow } \\
\text { the lecture later, equal } \\
\text { opportunity in education is } \\
\text { provided. }\end{array}$ & 3.72 & 1.271 & 10 & 10.8 & 3 & 3.2 & 22 & 23.7 & 26 & 28.0 & 32 & 34.4 \\
\hline $\begin{array}{l}\text { Before entering distance } \\
\text { education lessons, I needed } \\
\text { more preparation than formal } \\
\text { education lessons. }\end{array}$ & 3.14 & 1.426 & 16 & 17.2 & 15 & 16.1 & 27 & 29.0 & 10 & 10.8 & 25 & 26.9 \\
\hline $\begin{array}{l}\text { I had difficulty distinguishing } \\
\text { students who actively } \\
\text { participated in distance } \\
\text { education classes. }\end{array}$ & 2.97 & 1.410 & 21 & 22.6 & 12 & 12.9 & 27 & 29.0 & 15 & 16.1 & 18 & 19.4 \\
\hline $\begin{array}{l}\text { I don't think distance } \\
\text { education is beneficial. }\end{array}$ & 2.55 & 1.238 & 25 & 26.9 & 19 & 20.4 & 29 & 31.2 & 13 & 14.0 & 7 & 7.5 \\
\hline
\end{tabular}

The data of the opinions obtained from the academicians regarding distance education are shown in Table 3. Accordingly, most of the academicians (73.2\%) stated that they prepared for the lesson in advance and prepared the necessary course materials themselves. $73.1 \%$ of the academicians stated that they uploaded these materials to the system so that students would not be aggrieved. Although the majority of the academicians (68.9\%) find distance education inadequate, especially in applied courses, they think that this education system can be a solution in extraordinary processes. In addition, academicians generally think that they do not find distance education alone sufficient $(67.8 \%)$, it is difficult to attract students' attention to the lesson, therefore students do not participate in the lesson adequately (48.4\%) and do not show interest (48.4\%). It was stated that the students were not as active in the lessons as they were in formal education $(48.4 \%)$. Among the reasons for these may be; the infrastructure of the 
distance education system is insufficient and the students have not enough technological equipment.

In order to determine whether there is a significant difference in the opinions of academians about distance education by gender, an independent samples t-test was performed and the data regarding the findings are shown in Table 4.

Table 4. The Results of the Independent Samples t-test Conducted on the Opinions of Distance Education According to the Gender Variable

\begin{tabular}{|l|l|c|c|c|c|c|c|c|}
\hline & Gender & $\mathbf{N}$ & $\overline{\mathbf{x}}$ & SD & $\mathbf{t}$ & $\mathbf{d f}$ & $\mathbf{p}$ & $\mathbf{d}$ \\
\hline $\begin{array}{l}\text { Academians' views on } \\
\text { distance education }\end{array}$ & Female & 42 & 3.08 & 0.828 & \multirow{2}{*}{2.056} & 91 & \multirow{2}{*}{$\mathbf{0 . 0 4 3}^{*}$} & \multirow{2}{*}{0.30} \\
\cline { 2 - 10 } & Male & 51 & 2.84 & 0.757 & & \\
\hline
\end{tabular}

When Table 4 is examined, it is seen that the arithmetic mean scores of the answers given by the female participants to the questionnaire items are higher than the male participants (Female $\bar{x}=3.08$, Male $\bar{x}=2.84$ ). As a result of the t-test, the difference was found to be significant $(p<0,05)$. According to this result, it can be said that the opinions of female participants regarding distance education are more positive than male participants. In addition, the effect size (d) was calculated as 0.30 . If the effect size is less than 0.20 , it can be defined as weak, if greater than 0.80, it can be defined as strong, in other cases, it can be defined as a medium. Accordingly, it can be said that the effect size is medium.

ANOVA test was conducted in order to determine whether there is a significant difference in the opinions of academians regarding distance education according to the age variable and the information about the findings is shown in Table 5.

Table 5. ANOVA Results According to the Age Variable of Academians Views on Distance Education

\begin{tabular}{|c|c|c|c|c|c|c|}
\hline \multirow{9}{*}{$\begin{array}{c}\text { Academians' views } \\
\text { on distance } \\
\text { education }\end{array}$} & \multicolumn{3}{|c|}{ Age } & $\mathbf{N}$ & $\overline{\mathbf{x}}$ & SD \\
\hline & \multicolumn{3}{|l|}{$23-33$} & 28 & 3.03 & 0.467 \\
\hline & \multicolumn{3}{|l|}{$34-44$} & 38 & 2.88 & 0.624 \\
\hline & \multicolumn{3}{|l|}{45 and over } & 27 & 2.96 & 0.521 \\
\hline & \multicolumn{3}{|l|}{ Total } & 93 & 3.54 & 0.548 \\
\hline & Source of Variance & SS & df & MS & $\mathbf{F}$ & p \\
\hline & Between Groups & 0.332 & 2 & 0.166 & 0.546 & 0.581 \\
\hline & Within Groups & 27.331 & 90 & 0.304 & & \\
\hline & Total & 27.663 & 92 & & & \\
\hline
\end{tabular}

According to Table 5, it is seen that there are differences between the ages of the participants and their views on distance education. As a result of the ANOVA test conducted to determine whether the difference is significant, it was determined that the difference was not significant( $p>0.05)$. According to this result, there is no significant difference between the views of academicians on distance education and their ages. 
Table 6. ANOVA Results According to the Title Variable of Academians Views on Distance Education

\begin{tabular}{|c|c|c|c|c|c|c|}
\hline \multirow{11}{*}{$\begin{array}{c}\text { Academians' views } \\
\text { on distance } \\
\text { education }\end{array}$} & \multicolumn{3}{|c|}{ Age } & $\mathbf{N}$ & $\overline{\mathbf{x}}$ & SD \\
\hline & \multicolumn{3}{|l|}{ Lecturer } & 30 & 3.02 & 0.260 \\
\hline & \multicolumn{3}{|l|}{ Lecturer Dr. } & 11 & 3.19 & 0.207 \\
\hline & \multicolumn{3}{|l|}{ Assistant Prof. } & 26 & 3.04 & 0.471 \\
\hline & \multicolumn{3}{|l|}{ Associate Prof. } & 16 & 3.10 & 0.263 \\
\hline & \multicolumn{3}{|l|}{ Professor } & 10 & 3.05 & 0.233 \\
\hline & \multicolumn{3}{|l|}{ Total } & 93 & 3.06 & 0.325 \\
\hline & Source of Variance & SS & df & MS & $\mathbf{F}$ & $\mathbf{p}$ \\
\hline & Between Groups & 0.255 & 4 & 0.064 & 0.594 & 0.668 \\
\hline & Within Groups & 9.451 & 88 & 0.107 & & \\
\hline & Total & 9.706 & 92 & & & \\
\hline
\end{tabular}

According to Table 6, it is seen that there are differences between the titles of the participants and their views on distance education. As a result of the ANOVA test conducted to determine whether the difference is significant, it was determined that the difference was not significant(p>0.05). According to this result, there is no significant difference between the views of academicians on distance education and their titles.

Table 7. ANOVA Results According to the Experience Variable of Academians Views on Distance Education

\begin{tabular}{|c|c|c|c|c|c|c|}
\hline \multirow{11}{*}{$\begin{array}{l}\text { Academians' views } \\
\text { on distance } \\
\text { education }\end{array}$} & \multicolumn{3}{|c|}{ Age } & $\mathbf{N}$ & $\overline{\mathbf{x}}$ & SD \\
\hline & \multicolumn{3}{|l|}{$0-3$ years } & 26 & 3.13 & 0.212 \\
\hline & \multicolumn{3}{|l|}{ 4-7 years } & 9 & 2.97 & 0.270 \\
\hline & \multicolumn{3}{|l|}{$8-11$ years } & 29 & 3.06 & 0.450 \\
\hline & \multicolumn{3}{|l|}{ 12- 15 years } & 11 & 3.04 & 0.322 \\
\hline & \multicolumn{3}{|l|}{16 years and over } & 18 & 3.02 & 0.252 \\
\hline & \multicolumn{3}{|l|}{ Total } & 93 & 3.06 & 0.325 \\
\hline & Source of Variance & SS & df & MS & $\mathbf{F}$ & p \\
\hline & Between Groups & 0.255 & 4 & 0.056 & 0.523 & 0.719 \\
\hline & Within Groups & 9.481 & 88 & 0.108 & & \\
\hline & Total & 9.706 & 92 & & & \\
\hline
\end{tabular}

According to Table 7, it is seen that there are differences between the experiences of the participants and their views on distance education. As a result of the ANOVA test conducted to determine whether the difference is significant, it was determined that the difference was not significant $(\mathrm{p}>0.05)$. According to this result, there is no significant difference between the views of academicians on distance education and their experiences.

In order to determine whether there is a significant difference between the state of thinking that distance education is an effective model and their views on distance education, an independent samples t-test was conducted and the result is shown in Table 8.

Table 8. Independent Samples t-Test Results Regarding Distance Education Views

\begin{tabular}{|l|l|l|l|l|l|l|l|c|}
\hline & Answer & $\mathbf{N}$ & $\overline{\mathbf{x}}$ & SD & t & df & p & d \\
\hline \multirow{2}{*}{$\begin{array}{l}\text { Do you think distance education } \\
\text { is an effective model? }\end{array}$} & Yes & 40 & 3.25 & 0.473 & \multirow{2}{*}{-5.342} & \multirow{2}{*}{91} & \multirow{2}{*}{$\mathbf{0 . 0 0 0}$} & \multirow{2}{*}{1.10} \\
\cline { 2 - 6 } & No & 53 & 2.72 & 0.491 & & & \\
\hline
\end{tabular}

As seen in Table 8, academicians who consider distance education to be an effective model have more positive opinions on distance education $(\overline{\mathrm{x}}=3.25)$. The opinions of the academicians who do not see distance education as an effective model and who are reluctant are more negative 
$(\overline{\mathrm{x}}=2.72)$. According to this; It can be concluded that academicians' views on distance education will diverge positively by carrying out activities that enable them to see distance education as an effective model. In addition, the effect size (d) was calculated as 1.10. Accordingly, it can be said that the effect size is strong $(d>0.80)$.

\section{CONCLUSIONS AND SUGGESTIONS}

The COVID-19 epidemic, which has affected the whole world as of December 2019, has made unconventional innovations mandatory in the education system, and distance education has become indispensable for all levels of educational institutions. Most private or public educational institutions were caught unprepared for this process and both students and teachers encountered some technical problems [16]. In addition, the lack of internet connection or low connection speed, inability to use technological devices effectively and correctly, low level of digital literacy, insufficient software/hardware caused the emergence of various problems [17]. All these problems cause divergence on the views of academicians who had to teach their lessons with distance education. For this reason, it is the purpose of this study to determine the level of academicians' views on distance education. When the data obtained for this purpose were examined, the following results were encountered:

- The results of the research showed that the general views of the participants on distance education were undecided. Although this result supports the literature [18-21], there are also studies in which participants have positive [22] and negative views on distance education $[23,24]$.

- Although there are studies in the literature showing that male participants have more positive opinions about distance education [25, 26] or that there is no significant difference in terms of gender [27], our research results show that female participants have more positive views.

- Approximately half of the academicians participating in the study $(48.4 \%)$ stated that students did not participate in the lessons taught by distance education, and the vast majority $(67.7 \%)$ thought that students were not as active as the formal education lessons in these lessons. These results support the studies in the literature that conclude that student participation in distance education lessons is low [17, 28, 29].

- Many studies in the literature revealed that problems are experienced and students face various difficulties, especially during the delivery of practical courses with distance education $[3,6,24]$. In our study, a large part of the participants $(68.9 \%)$ thinks that practice-based courses will not be effective with distance education.

- Research in this field is not an orientation study on distance education for academicians. For this reason, it has revealed that they have some problems in the distance education environment $[22,30]$. As a matter of fact, $83.9 \%$ of the academicians who participated in our research stated that they had not received any orientation training related to distance education.

- $47.3 \%$ of the participants stated that distance education is not as beneficial to students as formal education and formal education is more effective than distance education, $67.8 \%$ of them stated that distance education alone is not enough. The positive and negative aspects of distance education have led to the need to mix distance education and formal education in education, and in a study, it was observed that the information provided with the blended learning method was more permanent [31]. 
- Lastly, $50.5 \%$ of the participants stated that the exam, project, homework, etc. which was done by distance education evaluations were not very reliable and they should be face to face. This result supports the literature [30].

The following suggestions can be made in line with the results of our research:

- Studies can be conducted to support the active participation of students in distance education lessons.

- Orientation studies related to distance education can be made for trainers (academicians).

- In-service training on technology literacy and computer-aided education can be given to academicians working in higher education.

- More resources can be allocated to distance education infrastructure studies of universities and $R \& D$ activities on this subject.

- The reliability of online exams can be increased with face recognition technologies and various software.

\section{REFERENCES}

[1] Sindiani, A.M., Obeidat, N., Alshdaifat, E., Elsalem, L., Alwani, M.M., Rawashdeh, H., Fares, A.S., Alalawne, T. and Tawalbeh, L.I. (2020). Distance education during the COVID-19 outbreak: a cross-sectional study among medical students in North of Jordan, Annals of Medicine and Surgery, 59: 186-194.

[2] Qazi, J., Nseer, K., Qazi, A., Al Salman, H., Naseem, U., Yang, S., Hardaker, G. and Gumaei, A. (In Press). Evolution to online education around the globe during a SARS-Cov-2 Coronavirus (COVID-19) pandemic: do develop and underdeveloped cope alike?, Children and Youth Services Review, DOI: https://doi.org/10.1016/j.childyouth.2020.105582

[3] Kurnaz, E. and Serçemeli, M. (2020). Covid-19 Pandemi Döneminde Akademisyenlerin Uzaktan Eğitim ve Muhasebe Eğitimine Yönelik Bakış Açıları Üzerine Bir Araştırma, USBAD Uluslararası Sosyal Bilimler Akademi Dergisi, 2(3): 262-288.

[4] Lee, S.J., Ward, K.P., Chang, O.D. and Downing, K.M. (In Press). Parenting Activities and the Transition to Home-based Education During the COVID-19 Pandemic, Children and Youth Services Review, DOI: https://doi.org/10.1016/j.childyouth.2020.105585

[5] Chang, T.Y., Hong, G., Paganelli, C., Phantumvanit, P., Chang, W.J., Shieh, Y.S. and Hsu, M.L. (In Press). Innovation of Dental Education During COVID-19 Pandemic, Journal of Dental Sciences, DOI: $\underline{\text { https://doi.org/10.1016/j.jds.2020.07.011 }}$

[6] Kahraman, M.E. (2020). COVID-19 Salgınının Uygulamalı Derslere Etkisi ve Bu Derslerin Uzaktan Eğitimle Yürütülmesi: Temel Tasarım Dersi Örneği, IMÜ Sanat Tasarım ve Mimarlık Fakültesi Dergisi, 6(1): 44-56.

[7] Koloğlu, T. F., Kantar, M. and Doğan, M. (2016). Öğretim Elemanlarının Uzaktan Eğitimde Hazırbulunuşluklarının Önemi, $A U A d, 2(1): 52-70$.

[8] Ifijeh, G. and Yusuf, F. (2020). COVID - 19 Pandemic and the Future of Nigeria's University System: The Quest for Libraries' Relevance, The Journal of Academic Librarianship, 46: 1-8.

[9] Wijesooriya, N.R., Mishra, V., Brand, P.L.P. and Rubin, B.K. (2020). COVID-19 and Telehealth, Education, and Research Adaptations, Pediatric Respiratory Reviews, 35: 38-42.

[10] Rajhans, V., Memon, U., Patil, V. and Goyal, A. (2020). Impact of COVID-19 on Academic Activities and Way Forward in Indian Optometry, Journal of Optometry, 13: 216-226. 
[11] Mishra, L., Gupta, T. and Shree, A. (In Press). Online Teaching-Learning in Higher Education during Lockdown Period of COVID-19 Pandemic, International Journal of Educational Research Open, DOI: https://doi.org/10.1016/j.ijedro.2020.100012

[12] Karasar, N. (2008). Bilimsel Araştırma Yöntemi. (18th edition) Ankara: Nobel Yayınevi.

[13] Basturk, S. and Tastepe, M. (2013). Bilimsel Araştırma Yöntemleri. (Chapter 5) Ankara: VizeYayıncılık.

[14] McKillup, S. (2012). Statistics explained: An introductory guide for life scientists (Second edition). United States: Cambridge University Press.

[15] Shapiro, S. S., and Wilk, M. B. (1965). An analysis of variance test for normality (Complete samples), Biometrika, 52(3/4): 591-611.

[16] Keskin, M., and Özer-Kaya, D. (2020). COVID-19 sürecinde öğrencilerin web tabanlı uzaktan eğitime yönelik geri bildirimlerinin değerlendirilmesi, İzmir Kâtip Çelebi Üniversitesi Sağllk Bilimleri Fakültesi Dergisi, 5 (2): 59-67.

[17] Bakioğlu, B., and Çevik, M. (2020). COVID-19 pandemisi sürecinde fen bilimleri öğretmenlerinin uzaktan eğitime ilişkin görüşleri, Turkish Studies, 15(4): 109-129.

[18] Gürer, M.D., Tekinarslan, E. and Yavuzalp, N. (2016). Çevrimiçi ders veren öğretim elemanlarının uzaktan eğitim hakkındaki görüşleri, Turkish Online Journal of Qualitative Inquiry, 7(1): 47-78.

[19] Birişçi, S. (2013). Video konferans tabanlı uzaktan eğitime ilişkin öğrenci tutumları ve görüşleri, Öğretim Teknolojileri ve Öğretmen Ĕ̈itimi Dergisi, 2(1): 24-40.

[20] Cabı, E., and Erhan, G.K. (2016). Uzaktan eğitim ile istatistik öğretimine yönelik öğrenci görüşleri, Eğitim ve Ögretim Araştırmaları Dergisi, 5(1): 104-111.

[21] Tekin, O. (2020). Uzaktan eğitim kullanılan hizmet içi eğitim programlarına yönelik öğretmen görüşlerinin Incelenmesi, Eğitimde Kuram ve Uygulama, 16(1): 20-35.

[22] Kılıç, E., Baran, B., Bakar, A., Çağıltay, K., Konukseven, E.İ., Yalabik, N. and Toroslu, İ.H. (2006). Üniversite öğretim üyelerinin internet üzerinden eğitim konusundaki görüşleri, Eurasian Journal of Educational Research, 22: 159-165.

[23] Çelen, F.K., Çelik, A.. and Seferoğlu, S.S. (2013). Analysis of teachers' approaches to distance education, Procedia-Social and Behavioral Sciences, 83: 388-392.

[24] Kaya, M., Çitil-Aksoy, C., Özbek, R. and Pepeler, E. (2017). Lisansüstü eğitim programlarinda 'uzaktan eğitim uygulamasina' yönelik 'eğitim bilimleri bölümü’ akademisyenlerinin görüşleri, Elektronik Sosyal Bilimler Dergisi, 16(64): 1616-1627.

[25] Öztaş, S. and Kılıç, B. (2017). Atatürk ilkeleri ve inkilâp tarihi dersi'nin uzaktan eğitim şeklinde verilmesinin üniversite öğrencilerinin görüşleri açisindan değerlendirilmesi (Kırklareli Üniversitesi örneği), Turkish History Education Journal, 6(2): 268-293.

[26] Buluk, B. and Eşitti, B. (2020). Koronavirüs (COVID-19) sürecinde uzaktan eğitimin turizm lisans öğrencileri tarafindan değerlendirilmesi, Journal of Awareness, 5(3): 285-298.

[27] Kırali, F.N. and Alcı, B. (2016). Üniversite öğrencilerinin uzaktan eğitim algisina ilişkin görüşleri, Istanbul Aydın Üniversitesi Dergisi, 30: 55-83.

[28] Sintema, E.J. (2020). Effect of COVID-19 on the Performance of Grade 12 Students: Implications for STEM Education, EURASIA Journal of Mathematics, Science and Technology Education, 16(7): 1-6.

[29] Zan, N. and Zan, B.U. (2020). Koronavirüsile Acil Durumda Eğitim: Türkiye'nin Farklı Bölgelerinden Uzaktan Eğitim Sistemine Dahil Olan Edebiyat Fakültesi Öğrencilerine Genel Bakış, Electronic Turkish Studies, 15(4): 1367-1394. 
[30] Tuncer, M. and Tanaş, R. (2011). Akademisyenlerin Uzaktan Eğitim Programlarına Yönelik Görüşlerinin Değerlendirilmesi (Frrat ve Tunceli Üniversiteleri Örneği), İlköğretim Online, 10(2): 776-784.

[31] Demirli, C. and Aksogan, M. (2012). The effect of blended learning on the persistence of academic performance for computer education, The Journal of Instructional Technologies \&Teacher Education, 1(1): 111122. 